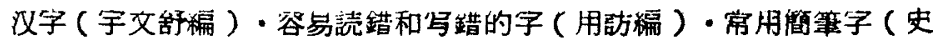

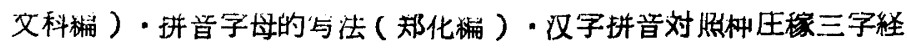

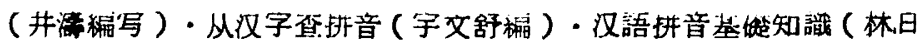

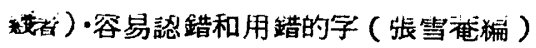

30. 怎样写信 上海教有出版社編 1964.9 稨者刊 p.33<工农道俗文庫>

31. 农利区用文 同上 1964.8 同上 $\mathrm{p} .38<$ 问上>

32. 农村应用文 四川人民出版社編 1964.9 編者刊 $\mathrm{p} .34$

33. 谷易写錯的字 徐仲华 1964.3 北京出版社 p.44<語文小丛垂3>

34. 訓詁浅談 䍆宗达 1964.3 . 北京出版社 p.62<語文小丝 $4>$

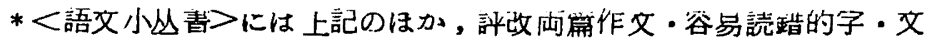

言詞法常識・詩詞格律十請 - 中国古代散文的発展 - 鲁迅和他的作品. 文学与社会生活・仪語拼音入門・赵树理的小説・常用字典辞典和覔 字法がある。

35. 小学語文教学中的動物知識 童一中編 1963.9 上海教育出版社 p. 101

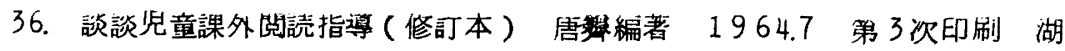
南人民出战社 p.99

37. 注音繞口令 刘明綱編注 1960.9 文字改革出版社 $p .54$

38. 西川应語第 2 集附: 歇後語 1964.8 四川人民出版社 $\mathrm{p} .65$

39. 外語教学 1964 年第 3 期 步龍江大学<外語教学>編輯委員会編輯出版 原<俄語教学与研究

以上

\title{
中、国語教 育
}

小林

立

$\leftrightarrow$

明治以后散戦までの日本に括ける中 国語教有の歴実を見れば明らかな速り
中国語は日本の中国大陸への進出・侵 略の道具として重視されて来た。すな わら中国語は「戦争語学」「集用語学」 
として重視されたが，英語・ドイツ語 フランス語などのように「文化語学」 としては报われなかった。西欧語は， 進んだ四欧文化を摄取し吸収するため の手段として考えられ，それらは政治 経済・軍事・文化・科学技術などと密 接に結びついて来た。西欧諸語は「文 化語学」たりえた。従って日本に打け る无欧諸語の語学教育は, 尃ら読本中 心・訳芜主義が採用されて来たのであ る。ところが中国語教有においては， 日本の国策に沿って大檑進出・侵略の ため，その実用性が惨先したから必然 的に口頭接先義を搂さるを得なか o

だが日本の敗戦は中国語教青からら 「戦争語学」という性格を成り立てせ る条件を爀った。日本の敗践は中国侵 略のための実用語学教育に大打慗を与 え，害用の場は極度に制限を蒙むるこ ととなった。しかし「戦争語学」とし ての途が閉ざされた時，中国語に対す る科学的研究が大きな発展をとげた。 それはこれまで安淔に「実用語学」 の途に杗ってきた中国語か語学として 反省する時期を経過し，留的発展を遂 げるための時期だったと言えるだろう。

他方，中華人民共和国の誕生とその 発展は新しい人間と新しい文化を㓣造 して来ている。従って，中国語教有に は新しい剘面がつ加えられた。すな わら中国語は「笑用語学」という基础 ないし伝皏の上に，新中国を知り学ぶ ための「文化語学」としての性格をむ
つことが喓請されている。中国語は

「文化語学」としての倒面を我耀的に 発展しうる条件を中国目具が創造しつ つあるのである。

日本の外国語教育は現在転換期にさ しかかっていると言う。これまでの訳 読主義加ら脱して，口嘎主義による外 国語学㿟の動きがあり，そのための語 学機械の埒入, 新しい教授法の研究な とが目指されている。このことは欧米 文化の撕取・吸収のためにとられた読 本中心・訳読主戔加 ら，「実用語学」 としての酉炏語教育が要求され，その 方法が問題になって来ているのである。 そ机は中国語か门穾用語学」に「文化 語学」の側面を充実する时期加到来し ているのとは逆の意味て，西欧語む大 きな䎟換期にあると言えるであろう。

従って「外国語」教育に括ける訳谠

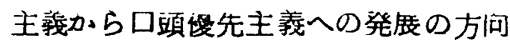
を手放しで歓迎するのは少し問題がか る。何故なら日本に物ける中国語教有 と西欧語教育とでは，根本的な差㝜が あったからである。中国語はこれまで 「実用語学」としての性格は強く要求 されて来た。しかし戦后 20 年は科学 的分析の時期であって，まだ「文化語 学」としての基磟と権威を碓立しては いないと言えるだろう。從って英語・ ドイッ語・フランス語などか，「文化 䛇学」としての権威の上に，「実用語 学」の側面を要誚されているのとは， 条件が䣏なるのである。四欧語に特け る「文化語学」から「実用語学」への 
発展は榄道がたっているが，中国語に 特いては「実用語学」から「実用語学」 では，「文化語学」の段階を経過でき 奴ことになろう。还って当面一般教育 としての中国語教青は「文化語学」の 側面を充箺することこそ大事なのでは ないか。

$\Leftrightarrow$

日本では中国語教有は大学に牺いて はじめて制度として現われる。徒って 中国語教育の主たる対象が大学生であ る点に特色がある。これは中学生が英 語を初めて学ぶ場台とは違う。中学生 は与えられた対象に絶体的価值を打い て学ぶが, 大学生は相対的佂値に括い てしか学ばない。相対性を強める条件 として大学では中国語の他に, 英語・ ドイツ語・フランス語・スペイン語・ ロンヤ語などの外国語が並存している。 大学生にとって中国語は外国語の一つ であって中学生に英語がすべてである のとは違う。従って大学生を対象とし た中国語の授業に岕っては，その方问 なり目標なり展望というものがちえら れる必要がある。それと共に做々の授 業に規律と魅力をむたせる必要がある。

そこで授業の規律について考えてみ る。中国語は西欧語と違って漢字で表 記されているので日本人には特永な外 囦棓として受けとられている。従って 学生は放任するとたちまち出席㳯は低 下する。だが初級に打いては発羔と基 的的な文法事項を学ばればなら奴っら 出帯日数に対して最低努力目標を設定
し出帛さぜねばならない。国家や四体 個人にそれぞれ努力目標が必要である ように，中国語の授業にすその出倐に ついて最低出席日数を学生に公約させ ることは是非とも必要なことである。 それ似は年間の出席日数では期間が長 すぎるから，前期・后期と区切ってそ れぞれの授菜日数を明らかにし，その 日数のうち，例えば三分の二以上出席 日数がなければ，受験資恪を失うとい った公約をとりつける。こうすること で学生は出帛そのこと自体に努力る强 いられ，たと元授業にいやい中出席す る学生であ中国語を学ぶことにつなが ることにもなる。出偣日数は皆勤を型 む必要はない。むし万欠席できる余裕 を設けることで最低線を守らせること が可能となる。出尔原を放任すること はよく出席する学生にまで影揫を放ほ し,クラス全体の士気を低下させる原 因となる。また，平常は欠席して扮い て試跧にだけ出席する学生を拒否する こともできなくなる。

出席をやかましくすることで，教師

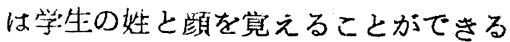
し，学生の中には皆勤ないし㫮勤に等 し、学生む現われて来る。クラス全崱 の士気を高めるには，出席そのものに 対しても目整をか加げ，教師は必ず実 行することである。公約を公約として 必らす奏行することは，学生の信用を からとる䢒であり，中国語の授兹の権 成をからとるための唯一の途である。 小学松・中学・高校と受物规強一胼 
に生きて来た大学生は，大学へ来てと たんに目分の生活の目醥・より所を失 ってしまって感じを持つ。大学の授荣 に休講が多かったりすることは，学生 の目主性の學重といえば皆えはよいが 一般的にはやはりさほりくせをつけさ せ，大学の投業そのあのに失望させる ことになる。

さて，一般教有としての中国語の授 莱心対して学生は何を求めて来るのか そして教師目身はどういう目唀をかか げ，与えれはよいのでろうか。中国語 は一般教青の外国語課目の一として 週二回，年間通じて学べば 4 単位に計 算される。だから学生の中には，中国 語をではなく「外国語」の单位のため に中国語を受講する者が多い。そうい う学生を含めて，週二回，年卓で 4 戦位ということが，とにかく学生の基 本的要求であることを教師は碓認して 特かねばならない。この基本的要求の 上にたって学生を分類すれば，单位さ え取れはよいという現実派と新吅国に 対して何らかの関心を持っている理想 派との型がある。単位だけが欲しい学 生は大体授業にむよく欠饰するから最 低出席日数の線を引いてこれらの学生 が授莱に及的影辢を防せが权はなら ない。こういう単位乞食にくらべると 新中国に対して园心を持って集る学生 は, 上く世席するか。，その学咟能率 あ艮好である。しかし新中国には大い に関心があるが，学生自治会・新期部 などで活端する学生は外国語として中
国語を学ら゙ことにはあまり興味を示さ ない。彼等は活趿に忙しく中国語の授 業す単位をとる手段とみなしているか ら，こういう個性的な学生に対しても 最低出席日数の公約がないと，授業を さほりて林るとになる。大学生 は目主的に勉強する要求をむっている が，やはり授業が学生にとって生活の 中心であるべきはずのものであり，出 席することが，席することより一般 的でなければならないだがそれには 教師目身が目分の授業に責任をむって 出来るだけ休傅などのないように努力 せねばならない。教師は授業すること がその紿の支払い対象になっている 以上, 職羓意識に徹する必妿がある。 授業は熱意をむって学生に対すること が必要である。教師の授菜に対する態 度は学生に敏感に反映する。学生を单 位への欲求に逆もどりさせる可能性は 常に存在しているのである。

日本では英語・ドイツ語・フランス 語などにくらべると中国語は幸か不幸 か参考鼠，辞韭・ソノンート・ラジオ 棓坐などのいずれに扣いても㮔類が少 ないたが英語やドイツ語の教師が 臿占に溢れるばかりの参考書類に㴹わ される学生を相手にするのとは连って 教室の授業を充奏すれば，直らに学生 の注惫を投菜に集中させやすい条件に ある。それだけ中国語の教師に゙英語の 教岵などにくらべると教えがいのある 外国語であると言えるのである。

あしまた学生に外国語の単位以上の 
あのを要求させたければ,どうしても 教㸝自身が学生に中国語を学ぶ总義と ウィションを与える必装がある。教䀡 は中国語を学生に教えようと努刀する こと以上に，学生に中国語を学ほうと いう植極的な気持を持たせるよう柊め ることの方が教即たるもののより重要 な役割りである。それは単に学生に目 醥を与え，役等の士気を向めるための みならず，教师目身の士気を維持する ために必要である。人間は目己の行動 に使台感を持ちうる時，士気は最す高 まる。中国語の授業が制度としてある ので，その制度の上にあぐらをかいて 中国語を教元ればよいという姿勢に陮 いる危険から目己を変るためである。 学生は毎年交替するが，教師は交替し ないから，教师の授業に対する谚意工 夫を持就するためには，それが生活手 段であるということの他に，何らかの 使命感を見い山さずにはすまされない のである。

\section{(三)}

現在の日本では中国語は大学におい てはじめて学ばれる外国棓である。そ してクラスは初級・中級・上級の三段 階に分かれている。大学に括ける中国 語教青は「文化語学」の方问にあるが 初敉は発音と文法事項を学ばねに゙なら 加ら「奏用語学」としての性格をす っている。「文化語学」の性格を明ら かにして来るのは，中級・上紇の段階 であると言える。そこで先ず中国語の 初級の授莱について完よう。大学の中
国語の投業は演習である。從って講義 形式の搅羙と同じく100分授葁であ る。100分一林の授業をやるゃらぬ は教㸝の都台にもよるが，現在市敗さ れている初級用テキストは，100分 という時间を考虑して作成されている のだろうか。中国語は漢字で表記され ているので，発音に重点をおいても， ドイッ語・フランス語・ロンヤ語・ス ペイン語などを初めて学ぶのとはだい ら造った杀件にある。初級用テキスト の例として光生館の「新しい中国語教 本一改訂增補基整篇」についてみる と,テキストの構成は文法事項が遂次 現われるよう配感され，参考例が付さ れたすぐれたテキストである。しかし その量について言えば，N H Kのラジ 才放送による「英語会話」栓传の分量 しかない。「英語会話」は無論初学者 を対哀としているのではないが，15 分という放送時間でこなせる栓度の量 しか大视の初用テキストが持ってい ないということは，初めて中国語を学 ぶというハンディキャップを考虑して あ輻的に不足しているのではなかるう か。又，漢字と発音が左右に分けて四了 㸝されているが，内谷の同じあのを継 面を二筫もさいて指成する必要はない のではないか。左右に漢字と発音が分 雄されていることにより，学生は右往 左往せねばならぬことになる。むしろ 漢肎の上，或いは下に発音を朾すのが 目然であり，その方が漢学と発昌を粘 びつけて覚え易いのてはないか。そし 
て余った一頁に参考のための例文を発 音を付して排列する方が，はるか心参 考例を発音と結びつけて活がる途な のではないか。そしてヌ、テキストで あるからには，学生が書き込みできる ように余日があった方がよいだろうか 5，B 6より少し大きめの方がよい。

現在市敗されている初級用テキスト は, 前の課の復習と新しい課をやって あ60分位あれば終えることができる。 全体で音読させたり，個別に読ませた り，単語を入れ替艺て日常使用できる 表晲を板書したり，文法的説明を加え てあ 100 分は要しない。それ以上问 じょうなことを絽り这しても学生の與 味を舅かせることはあまり期待できな いし,アクビが这って来万位のところ である。だいたいゔキストというもの は面白くないのが晋通であるが，基本 文型が現われると共に，会話に上る心 用例があっ幺登富にのせられてむよい のではなからうか。要するにもう少し 量的な肉付けがはしい。分量の少ない ことを板書によって補うことはすとよ り大事であるが，テキストそのあのが あう少し量を増すことで板㫪による時 間的口スを減らせることになる。

人間の注意力はせいせい2 0 分位し 持稰できないから，100分授業の 間には，紫張と他緩の過栓を二，三回 経過する。しかも，学生数加 50 人以 上にあなると, 一人の学生の言動であ ただらにクラス全貣に影豐を及はす。 例えば，授業が始って調子が出て来た
頃遅刻した学生が一人入って来てす， 全体の注意力をさまたげる作用をする。 注意を散俊にするすのは，教室内にと どます，室外に括ける物昌とか話し 声とかいろいろな条件がからみ台って 授亲をとりかこんでいる。従って教師 たるものクラス全員の注意力の行方を 敏感にキャッチしながら，その集中と 散僈の波に乗りながら，100分の授 業を創造してゆかねはななない。授羓 は教師による知識の切り売りの場とい った安䀛な過栓ではありえない。崱い 手の戝嘪意欲を計りながら，又冓売意 欲をそそりながら，いかにすればよく 売り込めるかというセールスの場であ り，教師と学生との格斗の場である。 授業は一回一回方創造であり，勝負で 南る。との日の授莱の良し蚛しは，学 生の注意力を如何に集中しえたかにあ ることは言うまでもないが，むしろ注 意力が散僈になった時に，とう対処し その波を莱り切れたかにかかっている。 テキストと関連のある話題を用意して 物くとか，時々のニニースを綒介する とか，一定のテーマを定めて連続的に 話をするとか，中国で琴在流行してい る歌曲を紹介し聞かせるとか，いろい ろ工夫せねばならない。学生の注意が 散慢になったとき，話題を転换するこ とにより，その波に采ることができた ら，次に来る集中への波を創り出すこ とができる。分呈の少ないテキストを 便用することは，100分授莱を教師 の創意工夫による授莱たらしめるため 
には都台がよいが，やはりもう少し量 を必慗とするのではないか。

中国語教育はこれまで「箺用語学」 として長い伝統を持って来たのだが， 初效用テキストに結台したソノンート 録音テープなどの不充分さが目につく。 理想を言えばテキストには必らずその テキストの録首テープなりソノンート が対伈して作成されるべきである。現 状はテキストとソノンート・録㫮テー プの結台したテキストああるが，全般 的にはてんでんばらばらの観を免かれ ない。ドイツ語の先生の話では，ドイ 語のテキストにはトイイッ人が吹込ん だ録音テープが教帽に贉呈されて和る それを教室で使っていると聞く。中国 語教刦に扔ける「実用語学」の側面を より尤実させるためにも，まずテキス 卜仙は必らずテープなりンノンートが 付いているといゔ状態る期する必要が ある。それには，やはりテキストの大 量使用が前提であり，本誌141号で 删須消先生が提喈されている如人，体 系的なテキストの存在が必要である。 初級用テキストなどは大抵队产的には 似かよっているから，もっと㮔類を减 らすなりして，重点的に使用す秃ば， テキストの值段む安くなるのではない

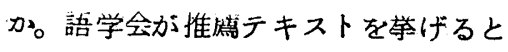
か,テキストは録音テープなりソノン 一トの付いているものでなければ使用 しないという条件を付すとかするのも 一の方法ではあるまいか。少なくと あ初敞用テキストには䟿音テーフ・・
ノンートが付くというのが, 早く常識 とならねばならない。

(144)

新中国の発展は中国語を「実用語学」

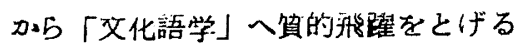
条件をそなえさせつつある。それにす かかかわらす国語はまだ英語・ドイッ 語・フランス語などにくらへてみて䓡 視される傾问がある。それはたとえば 害店へ行って兒ればよくわかる。私は 高松市の例しか知らないが, 英語・ド イッ語・フランス語・スペイン語・ロ シヤ語などのN H K のラジオ・テキス トはいどこの翼沾へ行ってあ必らず 並んでいる。これに対し中国語のうジ オ・テキストはほとんどその努を見か けたことがないのである。これは一体 どういうことなのか。青质い話では， 中国語のラジオ・テキストは5部はど とり奇せているということだった。だ がそれにしてむすぐ茜り切れてしまう のなら，何故もっと英語やドイッ語・ フランス語などのように少しは壳れ残 る位の册数をとりよせようとはしない のか。N H K で鐘ケ江信光先生が中国 語のラシオ整坐を担当されていても， 一般の人々や学生にそのテキストが手 に入らぬようでは因るし，そういうう シオ講坐そのものがあるるいうことを 広く一般に知らせるためにも，ラジオ テキストは佔頭に余分に亚べさせる必 要があるう。うジオ・テキスト交分 にとりよせても，売れることが証明さ れれば，書沾は必らす少し余分しとり 
よせてくれるはずでる。我々は行き つけの畨占に対して中国語のラシオ・ テキストを余分にならへるよう要求す べさである。

又，彷来の日本に打いては，その文 化は西欧語と密接に結びついて特け， 制攴として有利な地位を占めている。 たとえば経減学部心学生が大学院に進 学しようとすれば中国語ではなしにド イツ語を学ぶことが要求される。宸学 部に狺いては第二外国語はドイツ語を 必修としている。新中国の誕生以来 15 年経った現在に打いて，中国語は 教剖制医の上において末た「文化語学」 としての地位と椎威を砤立できていな いわけである。だが, ロンヤ語が戦后 ソ連の目覚しい科学的発度の前に, 文 学毣から理工系の分野に括いてお口ン ヤ語学酱の必要を創り出した如く，中 园語む中国目体の発展により「丰用語 学」的価値の上に,「文化語学」とし ての価値を俑えて来ることはすはや時 間の問題でしかない。彷って, 我々は 中国語を「実用語学」にとどめること なく，「文化語学」として学ぶため読 本中心主賤の採用と読本用テキストの 整備が必岁となって来よう。，そこで愣 在市欺されている読本用テキストにつ いてみると，問題になるめ溌音であ る。佧って読本テキストとして初秛を 終えた学生加学ぶ场台，まず「注音テ キスト」であることが必要杀件である。 この望求に適したあのとして「注羙現 代中国語読本」（大安）「注音中国語
テキスト」(光生館）「注音奏践論矛 盾論」（大安），「注音阿Q正伝」 （光生館）などが挙げられている。た た「驻音実践許矛盾論」の拼音につい て言えば，扳井健一先生が「大安」

（1965.5)で指摘されているように 柽声については梚討されてょいと思う。 この他，注音という点で上級あたりで しか使えないテキストとして，「新し い中国語教本一読本篇」(光生館) 「解説注音桨聖㯁童話選」( 光生䗆) 「註勫注音宝船」(光生館)「毛澤東

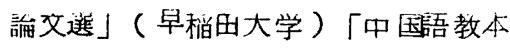
読本粫下」(白水社)などがある。今 年の苩, 金子二郎先生の還暦を祝って 光生館から出版された「中国語と中国 文化」は，香坂順一先生のすぐれた。 想と会負有志の力に上る中国語読本で あるぶ, 第二外国語の学生のテキスト として見ると注音のないことと，中国 語の原文が少しつまりすぎている点が 惜しい。

他の大学に和ける中国語テキストの 使用状沙については知らないので, 香 川大学们例を報告すれば, 初級は週二 回あるので，前期は「新しい中国語教

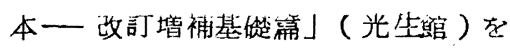
使用し，后期には「注音現代田茵語読 本」(大安)を便用する。中級・上秋 は造一可の授業であるが，中衵は，前 期に「注昌中国語テキスト」(光生館) を，後期には「中国語教本読本碖下」 （白水社）を便う。上級は「社吾実践 說矛盾論」(大安) と「注音阿 $Q$ 正沄」 
(光生館) を使う。香川大学の初級の 受講者は六十余名であるが，中級・上 秋は僅かに二〜三名づつしかいない。 日本の大学に持ける中国語学習者の実 態調疽の資料を持厄如ので，全体を推 しはかることは危满だが，日本全体に

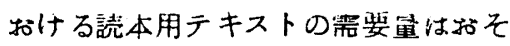
らくあまり务くはないのではないかと 思われる。読本用テキストの使用量の 絶体的不足が中国語の辞典類をトイッ 語やフランス語などにくらへて第くに と高㜀なむのにしているのではないか。 辞畟の倠段をさげるには，使用者そふ やさ极ばならない。それには，売本テ
キストの広顽な使用があってこそ可能 であり，根本的には中国語の受講者の 拡大が必姕である。これらはいずれむ 「质のない日に师をあげる」よう年努 力を要する。

以上私は目分のとほしい実践のなか で得た感想を述へて来たのだか，これ からの中国語教育は「文化語学」の方 问をとるへきであり，それには各大学 が条件に即して努力すると共に，全国 組織である本学会によってしか解決で き奴仕事を学会が棈歌的に上りあげて ゆく以外に途はないと考える。

(1465.7.30)

\section{第 16 回全国大会0あらまし}

中国語学所究会の第 16 回全国大会 は, 9月25日.26日.27日に

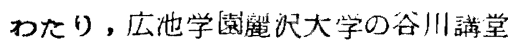
で開かれた。遠路にかがらす，参加 公崱は䄪 80 名に達し, 素朴な叟泉の 政を桨しみつつ，プログラムの予定ど おり，全行事を終わった。今年は個人 研究・分科会とあに，内谷が充奏して 牤り，会崱の熱心努力によって，学 界の水隼が著しく间上したことが，う かがわれた。当番砇となった簏㐸大学 では，奥平定世・有馬健之助仙公員を 始め, 多くの教官と学生諸君が忩力
挙げて，大会に拗力してくださった。 ここに厚く颃礼申しあげる。 粉会での決定事項

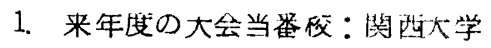
(大防府吹出市千里山) と決定した。 2. 会長選挙：投慗総数66紫の55

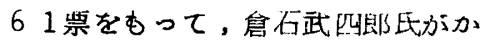
さねて造出された。な挌地の幹形

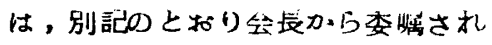
たので、ご承諾いただきたい。

3. 公誌糄集：牛盛德次・赖帷勤仙会 貪に，3年指にったつて稨集を特賴 いしてきたが，本年 10.11 月台併 